\title{
The Ways and Means of American Medicine
}

\section{Citation}

Allan M. Brandt. 1983. The ways and means of American medicine. Review of The social

transformation of American medicine, by Paul Starr. The Hastings Center Report 13(3): 41-43.

\section{Published Version}

http://www.jstor.org/stable/3561621

\section{Permanent link}

http://nrs.harvard.edu/urn-3:HUL.InstRepos:3372910

\section{Terms of Use}

This article was downloaded from Harvard University's DASH repository, and is made available under the terms and conditions applicable to Other Posted Material, as set forth at http:// nrs.harvard.edu/urn-3:HUL.InstRepos:dash.current.terms-of-use\#LAA

\section{Share Your Story}

The Harvard community has made this article openly available.

Please share how this access benefits you. Submit a story.

Accessibility 


\section{The Ways and Means of American Medicine}

by ALLAN M. BRANDT

The Social Transformation of American

Medicine. By Paul Starr. New York: Basic Books, 1983. 514 pp. \$24.95.

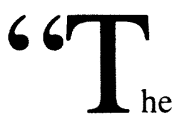

he history," medical logic holds, is the key to successful diagnosis. Buried in the past is the information that will make it possible for the doctor to treat the patient effectively. Sociologist Paul Starr takes this axiom to heart in a bold attempt to diagnose the current symptomatology of American medicine. Ambitious in scope, The Social Transformation of American Medicine traces the political economy of health care delivery in the United States over two centuries. Elegantly written and lucidly organized, Starr's book deserves the broad attention it is currently receiving. In sheer breadth alone Starr's study is remarkable; for years to come it will serve as a standard reference. In this respect Starr has filled a longfelt need for a single-volume, synthesized treatment of the development of the American medical profession.

The Social Transformation of American Medicine is divided into two "books." Book I traces the rise of the profession from an eclectic, competitive group of practitioners in the late eighteenth and nineteenth centuries to its current powerful role and high social status, a process that Starr argues was completed by the first decades of the twentieth century. Book II chronicles the profession's efforts to maintain its authority by fighting the introduction of third-party interests in medicine. In his conclusion, Starr forecasts the end of professional authority with the emergence of major corporations in the health care field, toppling the control of the individual practitioner.

Just as Starr's book breaks new ground, so too it reveals critical areas in the history of American medicine yet to be fully ex-

ALlan M. BRandT teaches history of medicine at Harvard Medical School and in the department of the history of science, Harvard University. plored. In particular, Starr does not sufficiently emphasize the role of science in the development of the profession. Nor does he take enough account of the historical primacy of the patient-physician relationship. The legitimacy and power of the profession that Starr attempts to detail"professional sovereignty" - cannot be fully understood without adequate attention to these two themes.

\section{The Role of Science}

Starr seeks to explain one of the most difficult questions in the history of American medicine: How did the weak, divided, insecure profession of the early nineteenth century become the authoritative cultural power of the twentieth? According to Starr, a number of factors explain this dramatic shift. Eager to avoid the traditional, positivistic explanation that scientific advances established the profession, helping it to restore order and discipline where competition had reigned, Starr's analysis essentially discounts the role of science. Instead, Starr places the triumph of the American profession in the particular social and cultural milieu of the late nineteenth century.

For the profession to gain sovereignty, access had to be restricted. The proprietary medical schools, organized to turn a quick profit for their owners, simply produced too many physicians, creating a highly competitive climate with many poorly trained doctors. In order to attract students from competing institutions, these schools tossed out all educational standards. The few instances when medical schools sought to raise standards during the midnineteenth century proved short-lived and costly as enrollments declined in favor of diploma mills. Starr views the demise of these proprietary institutions, which began in the last years of the nineteenth century and culminated in the years following Abraham Flexner's famous report of 1910 indicting the quality of American medical education, as a major factor in the rise of the profession.

The second major element in the modern development of the profession was the growth of local and state medical societies dedicated to limiting competition and offering legitimacy to their members while questioning the credentials and authority of nonregular practitioners. These societies, soon recognized by state legislatures, led to the third major change- -the restoration of medical licensing of physicians in the last decades of the nineteenth century. Licensing had been taken off the books during the egalitarian Jacksonian era as all claims of authority became suspect. "Every man his own physician," an oftcited motto, reflected the ideals of a number of medical sects that had come to question the benefits of copious bleeding and heroic purging.

Starr sees the professionalization of medicine occurring as American society underwent a revolution in transportation and communication, as cities and industry transformed the social fabric. The recognition of expertise, limited access to educational institutions, and higher instructional standards all led to what he calls "professional sovereignty," the formation of an economic monopoly on practice.

In the most inventive and original section of Book I, Starr analyzes the high indirect costs of the house call in travel time and the difficulty of locating physicians before the advent of modern communications and transportation. In this instance, through Starr's creative research, we get a glimpse of the hazards of practice, the travail of illness and health care in the premodern era. The lesson that Starr draws from this vignette of social history is, unfortunately, too narrow. Starr notes that physicians in the 1940s averaged from eighteen to twenty-two patients daily, compared to their nineteenth-century predecessors for whom five patients was a logistical maximum. "Such figures," writes Starr, "suggest a gain in productivity on the order of 300 percent." Such a comparison fractures historical time; an office visit in 1940 is not comparable to a house call in 1840. The real point is the remarkable qualitative difference in the very nature of practice, not the fact that doctors could see 
more patients and thus earn more money. What does it mean, for example, that doctors have spent significantly less time with their patients? Certainly other factors, beyond the doctor's desire to maximize income, explain this important change.

Starr's assessment of the development of the modern hospital also suffers from too narrow an emphasis on economic determinants. Starr identifies the "moral assimilation" of the hospital in the first decades of the twentieth century, the dramatic shift from home to institutional care. This new locus of medicine truly transformed the nature of illness and its treatment. Yet he focuses on the doctor's economic power to control the institution - the right to admit patients, the ability to fill beds.

The hospital, however, had even greater significance for cementing the authority of the profession; for it was, after all, the one place where lay people actually came into contact with the wonders of modern high technology. Even when these technologies were of little therapeutic benefit, their symbolic function was awesome. Who controlled this technology? Who explained it to the patient? Only as the doctor acquired this expertise were lay trustees forced to relinquish the administration of the hospital to the physician. This shift, Starr contends, was another element of the profession's insistence that nothing should stand between the doctor and the market. And yet this was no simple economic calculation; the physician's authority over hospital policy was grounded on the claims of scientific expertise; these claims soon granted the doctor authority to set policies of an essentially nonscientific nature. Science repeatedly offered the physician entree into the realm of social and cultural power.

Starr again gives short shrift to the influence of science in his treatment of the development of public health. In his view the battle lines in American public health have been drawn over the boundaries of who would provide care. Would the private physician or the state assume responsibility for those needing health care? Such a formulation, however, misses a critical point; both private doctors and public health officers adopted essentially the same model of health and disease during the first years of the twentieth century, a model that emphasized the need for individual medical attention rather than social interventions such as better nutrition or housing.

Why this was so demands further re- search and explanation. Starr, however, assumes that modern science is much the same in all Western nations and thus could not explain the distinctive nature of the profession in the United States. But in no other nation was the narrow biomedical model of specific causality of disease greeted with such uniform acclaim, especially among those committed to public health intervention. Doctors viewed germ theory through the prism of culture and society. To understand the cultural authority of the profession it is first necessary to understand that science is culturally constructed.

To say, for example, that medical advance had relatively insignificant impact on health before the introduction of antibiotics, as many historians now argue with much justification, is not to say that medicine did not accrue tremendous authority from science in the half-century from 1880 to 1930 . This, despite the fact that doctors during this period had little substantial to offer their patients, especially when compared to the period since World War II.

The social meaning of science and its particular allure to an American audience is in large measure absent from Starr's account of the rise of the profession, and yet it was the critical element. One need only look to Sinclair Lewis's medical epic Arrowsmith-Martin is one of the few heroes in modern American literature-or to Paul De Kruif's Microbe Hunters to garner some sense of this fascination with laboratory and clinic. Respect for science became the bedrock of American medical authority - the rise of the profession cannot be understood without it. Moreover, by avoiding any substantive discussion of the impact of science on the profession, Starr has, in a sense, tacitly accepted the notion that science is neutral and valuefree. The profession's ability not only to control medical knowledge, but to shape it as well, has been a fundamental aspect of twentieth-century medicine.

\section{The Physician-Patient Relationship}

Book II constitutes a more narrowly constructed analysis of health care politics in the twentieth century, in particular, the profession's rear-guard battles against the incursion of outside controls on practice, especially its opposition to federal insurance programs and prepaid group practice. The central focus of Starr's argument is the consideration of health care as a com- modity, one that the profession has consistently contended must-because of the unusual nature of the healing relationship_-be offered to the buyer (patient) directly by the producer (doctor).

Starr seems to distrust this rationale, to see it as a subterfuge on the part of the profession in order to maintain its power. But he never takes on this argument directly. What has been the significance of the doctor-patient relationship for determining the pattern of care that emerged in twentieth-century American medicine? And how has it changed over time? Though the AMA's persistent and largely successful efforts to keep the government out of health care are critical, as Starr clearly demonstrates, these overt political efforts fit into a larger pattern of cultural politics. The American medical profession's ability to maintain its power and authority was as much the result of private exchanges in the doctor's office as lobbying in congressional offices.

Considering the work of medical sociologists, historians, and anthropologists during the last decade in reconstructing the particular contexts of health, disease, and healing, Starr's study is surprisingly orthodox in its focus on the traditional political economy of medicine. How, for example, has this complex structure of health care that, Starr argues, was created largely at the behest of the profession, affected not just the quality of health care, but also the production and distribution of health and disease in our society? Moreover, how does this system of care affect the way our society identifies problems of disease and dependency?

Such questions are critical to understanding the social transformation of American medicine; yet they remain outside the framework of Starr's analysis. His book is less about the hows and whys of practice than about the ways and means; it is about the doctor's battle to establish exclusive rights to the clinical domain rather than the nature of practice within that sphere. The blood and guts of the practice of medicine are missing- the internal dynamics and value conflicts, the burden of illness, the power and limits of intervention. In short, this is antiseptic medicine.

Missing from Starr's account is any substantive discussion of physicians' incomes in the twentieth century. It is on this issue, however, that the historical tension between altruism and self-interest, obligation and elitism, is often brought forth, helping 
to articulate the ethical conflicts inherent in practice. But it is not the doctors who are the villains of Starr's book. Indeed, their grasp on American health care is quickly slipping. Rather, it is the so-called medical-industrial complex, the corporate ambulance-chasers who threaten to turn health care into franchise businesses like MacDonald's or Burger King.

Starr finds the prospect of an industry of multinationals replacing individual practitioners ominous. And indeed, the very notion of hospital chains offering sales on triple bypass surgery- "have it your way" - or factory rebates on renal dialysis machines offers a poor prognosis for American health care. Many physicians and patients will, no doubt, read Starr's conclusions and gasp; but it is his view that the corporation is here and the future is bleak, the result of a growing supply of doctors, federal mismanagement, and current political policies favoring the private sector.

How American medicine was able to embrace modernity through a new science, at the same time clinging to an essentially traditional system of health care provision-the independent practitioner working for fee-for-service-remains one of the most compelling paradoxes of twentiethcentury social history. Starr's excellent narrative does not make explicit how the profession was able to achieve such largely uncontested status and authority.

The answer to this question may well lie outside the realm of professional interest and politics. The faith in science; the reliance on experts; the social meaning and distribution of health and illness; the ultimate triumph of a therapeutic discourse, as well as the primacy of the doctor-patient relationship; all need to be considered more fully. Clearly, additional tests must be conducted before a differential diagnosis of the crisis of American health care may be offered. The fact that Starr's account makes this research agenda clear is to its credit. If the cure is to be found, it will require further investigations such as The Social Transformation of American Medicine.

\section{Morality and the Mundane by THOMAS H. MURRAY}

Moralities of Everyday Life. By John Sabini and Maury Silver, New York: Oxford University Press. 1982. \$19.95 hardcover; $\$ 6.95$ paperback.

\section{$M$} book. Written by two social psychologists, its thesis is that we cannot understand how people think and act without reference to

Thomas H. Murray is Associate for Social and Behavior Studies, The Hastings Center.
The convincing cases are very good indeed. Gossip, for example, allows people "to externalize, dramatize, and embody their moral perceptions." In sharing our disapproval of one person with a confidant, we ratify our own moral standards as concrete and correct, and convict the subject of gossip as a moral deviate. This is, I think, an accurate description of gossip's role in sustaining a community's confidence in its moral judgments.

Their discussion of flirtation, on the other hand, becomes a meditation on fudged intentions and the virtues of ambiguity: a study, that is, of ways to avoid moral disapproval through artful vagueness. Relevant to morality? Yes, in an amoral sort of way. Gossip, for one, is equally suited to support an abhorrent morality as an admirable one. (The American South, 1855: "Did you hear about that horrible Mr. Greeley? He wants to abolish slavery!')

Whether they realize it or not, the authors remain loyal to modern social science's commitment to "value-free" inquiry. Their descriptions, at times remarkably penetrating, at times strained and unpersuasive, are precisely that: descriptions, not prescriptions. Their only moral judgments are reserved for the least effective chapter in the book, much of it a stale paean to Stanley Milgram's familiar "obedience" research and its supposed relevance to the behavior of Nazi concentration camp guards. It also ignores recent scholarship disputing the meaning and significance of Milgram's studies. Sabini's and Silver's gifts for original and dispassionate analysis deserted them when needed most.

The book as I said is irritating-in part because it treats contemporary American morality as an ethnographer describes some exotic tribal rituals: from above, with no involvement. This is forgivable; it comes with the scientific tradition, I suppose. But the style of humor is culpable. They get off some genuinely funny lines. But too often the jokes are obscure and pedantic, a reminder to the readers how much more learned are the authors than they. Portions read almost like a Woody Allen parody of hip scientific prose.

Inventive and capricious, humorous and snide, Moralities of Everyday Life delights in paradoxes and ends up a paradox itself. Perhaps the authors' next effort will bring discipline to the originality apparent, but unharnessed, here. 